\title{
BMP-2 gene-fibronectin-apatite composite layer enhances bone formation
}

Wei Zhang ${ }^{1,4}$, Hideo Tsurushima ${ }^{1,2^{*}}$, Ayako Oyane ${ }^{1^{*}}$, Yushin Yazaki ${ }^{3}$, Yu Sogo $^{3}$, Atsuo $_{\text {Ito }}^{3}$ and Akira Matsumura ${ }^{2}$

\begin{abstract}
Background: Safe and efficient gene transfer systems are needed for tissue engineering. We have developed an apatite composite layer including the bone morphogenetic protein-2 (BMP-2) gene and fibronectin (FB), and we evaluated its ability to induce bone formation.

Methods: An apatite composite layer was evaluated to determine the efficiency of gene transfer to cells cultured on it. Cells were cultured on a composite layer including the BMP-2 gene and FB, and BMP-2 gene expression, $B M P-2$ protein concentrations, alkaline phosphatase (ALP) activity, and osteocalcin (OC) concentrations were measured. A bone defect on the cranium of rats was treated with hydroxyapatite (HAP)-coated ceramic buttons with the apatite composite layer including the BMP-2 gene and FB (HAP-BMP-FB). The tissue concentration of BMP2, bone formation, and the expression levels of the BMP-2, ALP, and $O C$ genes were all quantified.

Results: The apatite composite layer provided more efficient gene transfer for the cultured cells than an apatite composite layer without FB. The BMP-2 concentration was approximately 100 600 pg/mL in the cell-culture medium. Culturing the cells on the apatite composite layer for 27 days increased ALP activity and OC concentrations. In animal experiments, the tissue concentrations of BMP-2 were over $100 \mathrm{pg} / \mathrm{mg}$ in the HAP-BMPFB group and approximately $50 \mathrm{pg} / \mathrm{mg}$ in the control groups. Eight weeks later, bone formation was more enhanced in the HAP-BMP-FB group than in the control groups. In the tissues surrounding the HAP button, the gene expression levels of ALP and OC increased.
\end{abstract}

Conclusion: The BMP-2 gene-FB-apatite composite layer might be useful for bone engineering.

Keywords: bone engineering, BMP-2 gene-fibronectin-apatite composite layer, BMP-2 gene therapy, non-viral gene transfer.

\section{Background}

Some gene therapy systems have been reported for bone and cartilage tissue engineering in animal models [1-9]. Bone morphogenetic protein (BMP) genes have often been applied for bone repair, and their usefulness has been reported in various animal experiments $[1-5,8]$. BMP-2 is a potent osteoinductive factor shown to induce the osteogenic differentiation of mesenchymal cells [10], and treatment systems using recombinant BMP-2 protein show promise for the future. However, these systems using recombinant proteins have several problems, including high doses that range from

\footnotetext{
* Correspondence: hideo-tsurushima@md.tsukuba.ac.jp; a-oyane@aist.go.jp ${ }^{1}$ Nanosystem Research Institute (NRI), National Institute of Advanced Industrial Science and Technology (AIST), Higashi 1-1-1, Tsukuba, Ibaraki 3058565, Japan

Full list of author information is available at the end of the article
}

micrograms up to milligrams (which increases cost) and the short half-life of proteins [11].

A safe and efficient gene transfer system is in high demand in the field of tissue engineering. Gene-apatite particles have long been used as a gene-transferring agent [12-14]. A particulate gene-apatite composite offers increased safety over viral and lipid-based systems, because apatite is the main component of human hard tissues and has both low toxicity and good biocompatibility $[15,16]$. However, particulate gene-apatite composites have the disadvantage of inefficient gene transfer. To improve its efficiency of gene transfer, a surfacemediated gene transfer system derived from an apatite composite layer was recently developed [17]. We further improved the efficiency of gene transfer by immobilizing

\section{() Biomed Central}

(c) 2011 Zhang et al; licensee BioMed Central Ltd. This is an Open Access article distributed under the terms of the Creative Commons Attribution License (http://creativecommons.org/licenses/by/2.0), which permits unrestricted use, distribution, and reproduction in any medium, provided the original work is properly cited. 
cell adhesion molecules [laminin or fibronectin (FB)] in the apatite composite layer [18-20].

Hydroxyapatite has already been applied to various clinically approved bone substitutes to repair bone defects. Hydroxyapatite causes minimal foreign-body reactions and acts as an osteoconductive material by binding to bone $[21,22]$. Therefore, hydroxyapatite is a good material for use in operations, including cranioplasties, lamioplasties, and cervical anterior fusion. However, it has been reported that a significant amount of time is needed for hydroxyapatite to bind to host bones and achieve osteofusion. It would be ideal for substrates to bind to bone quickly.

We prepared an ethylene-vinyl alcohol copolymer $(\mathrm{EVOH})$ substrate coated by an apatite composite layer that includes both BMP-2 gene and FB (EVOH-BMP$\mathrm{FB})$ for in vitro experiments, and we prepared hydroxyapatite ceramic buttons (HAPs) with the apatite composite layer including the BMP-2 gene and FB (HAPBMP-FB) for in-vivo experiments. The aim was to evaluate the efficiency of gene transfer mediated by this apatite composite layer and the feasibility of using this gene transfer system in bone engineering.

\section{Materials and methods}

\section{Cell culture}

Mouse preosteoblast MC3T3-E1 cells, mouse embryonic mesenchymal cells, C3H10T1/2 cells and human cervical cancer HeLa cells were purchased from RIKEN Bioresource Center (Tsukuba, Japan). MC3T3-E1 and HeLa cells were cultured in minimum essential medium alpha (MEM $\alpha$; Gibco-BRL, Grand Island, NY, USA) medium including 10\% fetal bovine serum (FBS; Thermo Trace, Australia), and C3H10T1/2 cells were cultured in basal medium eagle (BME; Gibco-BRL) including 10\% FBS.

\section{Plasmid construction}

The DNA sources used were pGL3 control (Promega Co., Madison, WI, USA) and pCI-neo (Gibco-BRL). pGL3 control includes the cDNA of luciferase. The cDNA of human BMP-2 was inserted into the multiple cloning site of pCI-neo by using EcoRI and NotI sites at the linker ends, and it was named pCI-BMP. The cDNA of BMP-2 was cloned from HeLa cells by reverse transcription PCR. The cDNA was amplified using the following primers: forward primer, 5'-GCGGAATT CGACTGCGGTCTCCTAAAGGTC-3' and reverse primer, 5' - GCGGCGGCCGCTTGCTGTACTAGCGACACCCAC-3'.

\section{Preparation of substrates}

In in-vitro experiments, EVOH with a thickness of 1 $\mathrm{mm}$ was obtained by hot-pressing ethylene-vinyl alcohol copolymer pellets (quoted ethylene content of $32 \mathrm{~mol} \%$;
Kuraray Co., Ltd, Tokyo, Japan). The EVOH was cut into $10 \times 10 \mathrm{~mm}^{2}$ square substrates using a level-controlled sample cutter (SDL-200, Dumbbell Co., Ltd, Kawagoe, Japan). The EVOH was abraded on one side with $\mathrm{SiC}$ paper (average grain size $=7.6 \mu \mathrm{m}$, was ultrasonically washed with acetone and ethanol and was then dried under vacuum for $24 \mathrm{~h}$. HAP buttons were custom-made for the in-vivo experiments because it was not easy to form EVOH into the appropriate shape for in-vivo experiments and because HAP is a very popular biomaterial [23]. Pure, stoichiometric hydroxyapatite powder was supplemented with $3 \%$ (wt. \%) polyvinyl alcohol and 1\% (wt. \%) polyethylene glycol, sieved to select only particles under $75 \mu \mathrm{m}$ in size, then formed into disks at $98 \mathrm{MPa}$ and sintered at $1150^{\circ} \mathrm{C}$ for one hour. The resulting shape of the HAP buttons is shown in Figure four A, and each button has a surface area of $15.94 \mathrm{~mm}^{2}$ and a mean thickness of $1.00 \mathrm{~mm}$. The HAP buttons were designed for a round cranial bone defect 5 $\mathrm{mm}$ in diameter, and their sides were cut bilaterally to permit bone formation into the space that was created by cutting (Figure 1A).

\section{Deposition of amorphous calcium phosphate on the surface of the substrate}

Unlike HAP, EVOH has no nucleation site for apatite on its surface. Therefore, a surface modification process using amorphous calcium phosphate as a nucleating agent for the apatite was applied to the EVOH prior to the coating process [24-26]. EVOH was used in all of the in-vitro experiments. The EVOH was subjected to the following amorphous calcium phosphate-modification process, which was originally developed for an apatite coating process [27]. First, each substrate was dipped into $20 \mathrm{ml}$ of aqueous $200 \mathrm{mM} \mathrm{CaCl}_{2}$ (Nacalai Tesque, Inc., Kyoto, Japan) for $10 \mathrm{~s}$, then into ultrapure water for $1 \mathrm{~s}$, and then dried. Each substrate was then dipped into $20 \mathrm{ml}$ of aqueous $200 \mathrm{mM} \mathrm{K} \mathrm{HPO}_{4} \cdot 3 \mathrm{H}_{2} \mathrm{O}$ (Nacalai Tesque, Inc.) for $10 \mathrm{~s}$, then into ultrapure water for $1 \mathrm{~s}$, and then dried. The alternate dipping into calcium and phosphate ion solutions described above was performed three times. As a result of this process, nanoparticles of amorphous calcium phosphate, which is a precursor of apatite, were deposited onto each EVOH substrate [28].

\section{Coating process}

A calcium phosphate (CP) solution was prepared by dissolving $\mathrm{NaCl}$ (final concentration $=142 \mathrm{mM}$ ), $\mathrm{K}_{2} \mathrm{HPO}_{4} \cdot 3 \mathrm{H}_{2} \mathrm{O}(1.50 \mathrm{mM}), 1 \mathrm{M} \mathrm{HCl}$ solution $(40 \mathrm{mM})$, and $\mathrm{CaCl}_{2}(3.75 \mathrm{mM})$ (Nacalai Tesque Inc.) in ultrapure water and then buffering the solution at $\mathrm{pH}=7.40$ at $25^{\circ} \mathrm{C}$ with tris(hydroxymethyl)aminomethane (final concentration $=50 \mathrm{mM}$ ) and the necessary quantity of $1 \mathrm{M}$ 

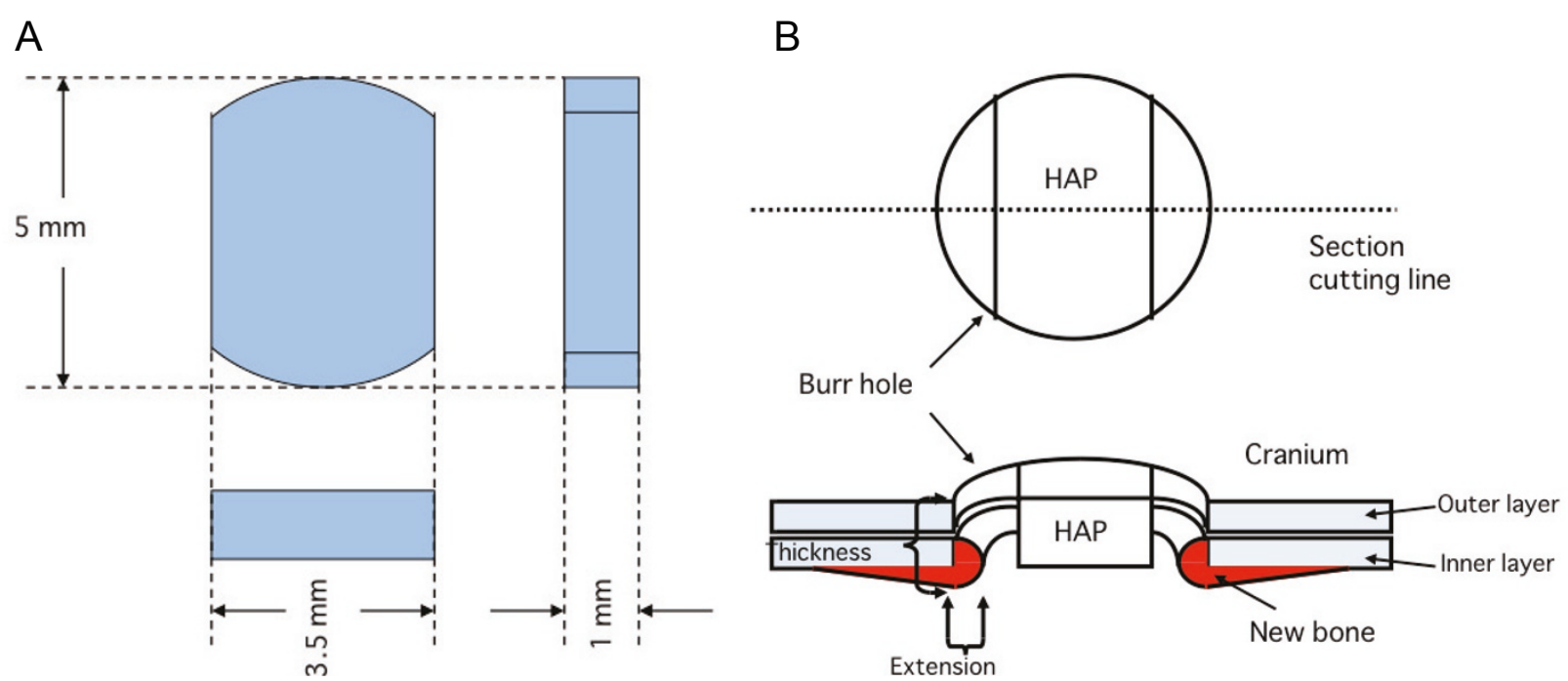

Figure 1 Three-dimensional views of a hydroxyapatite ceramic button (HAP) and the implantation of HAP samples into bone defects (burr holes). A; HAPs were made for cranial repair (cranioplasty) in rats. Both sides of the HAP were cut in order for bone formation to extend into the space around the bone defect. B; The panel demonstrates how bone formation was measured. Bone formation was quantified by measuring the length of new bone extension into the inside of the bone defect and the thickness of the edges of the bone defect.

HCl (Nacalai Tesque Inc.) [29-31]. Coating solutions were prepared by supplementing $C P$ solution with 40 $\mu \mathrm{g} / \mathrm{mL}$ of plasmid and/or $20 \mu \mathrm{g} / \mathrm{mL}$ FB. The FB source that was used was $1 \mathrm{mg} / \mathrm{mL}$ FB from bovine plasma (Sigma-Aldrich). The plasmid that was used was propagated and purified to a concentration of $0.7-1.2 \mathrm{mg} / \mathrm{mL}$. The EVOH was sterilized by exposure to ethylene oxide gas and then aseptically immersed in $3 \mathrm{~mL}$ of the coating solution at $25^{\circ} \mathrm{C}$ for $24 \mathrm{~h}$. The HAP was sterilized at $180^{\circ} \mathrm{C}$ for $6 \mathrm{~h}$ and immersed in $3 \mathrm{~mL}$ of the coating solution at $25^{\circ} \mathrm{C}$ for $24 \mathrm{~h}$. HAP lacking amorphous calcium phosphate deposition was treated in $2 \mathrm{~mL}$ of the coating solution at $25^{\circ} \mathrm{C}$ for $24 \mathrm{~h}$. The coating for these substrates was performed in $\mathrm{CP}$ solution alone or $\mathrm{CP}$ solution including plasmid and/or FB. The following materials were prepared:

- EVOH-CP and HAP-CP in CP solution alone.

- EVOH-FB in CP solution supplemented with FB.

- EVOH-DNA in CP solution supplemented with pGL3 control.

- EVOH-DNA-FB in CP solution supplemented with pGL3 control and FB.

- EVOH-BMP and HAP-BMP in CP solution supplemented with pCI-BMP.

- EVOH-BMP-FB and HAP-BMP-FB in CP solution supplemented with pCI-BMP and FB.

The coating solution was clear and showed no apparent spontaneous precipitation during the coating process. The substrate that was removed from the coating solution was gently washed with phosphate-buffered saline prior to the in-vitro or in-vivo experiments. The immobilized doses of calcium, phosphate, DNA, and FB were estimated by analyzing the residual coating solutions [18-20,23].

\section{Analysis of the surface of the samples}

The surface structures of the samples were examined by scanning electron microscopy (SEM; Model XL30, FEI Company, Netherlands). The amounts of fibronectin and plasmid immobilized on the samples' surfaces were estimated by analyzing the coating solutions by UV-vis spectrophotometry (Model V-550, JASCO Corporation, Japan) for any residual FB and plasmid after the coating. A protein assay kit (Bio-Rad Laboratories Inc., USA) was used to measure the FB concentration.

\section{In-vitro experiments}

The cells were seeded into a 24-well cell culture plate at a concentration of $2 \times 10^{4}$ cells/well with $0.5 \mathrm{~mL}$ medium. The cells were cultured on EVOH-CP, EVOHDNA, EVOH-DNA-FB, EVOH-BMP, or EVOH-BMP-FB for 3 days or 7 days. In some samples, the cells were washed three times with phosphate-buffered saline (PBS) and lysed in $200 \mu \mathrm{L}$ of cell culture lysis reagent (Promega). After vortexing, the supernatant was obtained by centrifuging. To evaluate the gene transfer efficiency, luciferase activity was measured in cells cultured on EVOH-DNA and EVOH-DNA-FB using a luminometer (Gene Light 55, Microtec, Japan) and a luciferase assay kit (Promega). Cells cultured on EVOH$\mathrm{CP}, \mathrm{EVOH}-\mathrm{BMP}$ and EVOH-BMP-FB were used to detect $B M P-2$ gene expression. 


\section{In-vitro bone development}

MC3T3-E1 cells were seeded into a 24-well cell culture plate at a concentration of $2 \times 10^{3}$ cells/well with 0.5 $\mathrm{mL}$ medium. The cells were cultured on EVOH, EVOHFB, EVOH-BMP, or EVOH-BMP-FB for 7 days or 27 days. The medium was replaced every week. In some samples, the cells were washed three times with phosphate-buffered saline (PBS) and lysed with $200 \mu \mathrm{L}$ of cell culture lysis reagent (Promega). After vortexing, the supernatant was obtained by centrifuging. Some samples were used to detect alkaline phosphatase (ALP) activity and osteocalcin (OC) concentration.

\section{Animal experiments}

During all of the experiments (which were approved by the Animal Care and Use Committee in The National Institute of Advanced Industrial Science and Technology), the animals were housed and handled in accordance with the guidelines of the National Institutes of Health. Seven- to eight-week-old male Wistar rats were purchased (Japan Crea Co., Ltd., Japan). Under anesthesia, a round craniotomy (5 $\mathrm{mm}$ in diameter) was drilled into the right parietal bone. The rats were divided into three treatment groups. In the HAP-CP group, the cranioplasty was performed with HAP-CP alone. The HAP-BMP group was treated with HAP-BMP without FB. The HAP-BMP-FB group was treated with HAP-BMP-FB. The rats were sacrificed at 2 and 8 weeks after the procedures, and the skull bones with the defects or bone defect tissues were removed. The bone samples were fixed in $10 \%$ formaldehyde in PBS for 4 days, demineralized in $10 \%$ ethylene diamine tetraacetic acid solution at $4^{\circ} \mathrm{C}$ for 3 days, and then embedded in paraffin and cut into 10$\mu \mathrm{m}$-thick sections. The samples were cut into the center of the skull defect (or at the nearest possible site) at a right angle across the lengthwise axis of the HAP button (Figure 1B). These sections were stained with hematoxylin and eosin and viewed using an IX71 microscope system equipped with DP-Controller imaging software (Olympus, Japan). In cranial bone healing, it has been reported that bone formation occurs at the periphery of the bone defect [32] and on the dural membrane side [33]. Bone formation was quantified by measuring the length of new bone extension into the inside of the bone defect and the thickness of the edges of the bone defect using the IX71 microscope system (Olympus) (Figure $1 \mathrm{~B})$. In some rats, the gene expression levels of $B M P-2$, $A L P$ and $O C$ and BMP-2 were evaluated in the tissues inside of the bone defects.

\section{$B M P-2, A L P$ and $O C$ gene expression}

The in-vitro cell samples were washed three times with PBS. The samples from the in-vitro cells or in-vivo tissues were homogenized and centrifuged, and the supernatant was used to extract RNA. Total RNA was extracted from some samples with an RNA extraction kit (QIAGEN). One microgram of total RNA was reverse transcribed in a buffer containing $1 \mu$ l of oligo$\mathrm{dT}$ primers $(2.5 \mu \mathrm{M}), 250 \mu \mathrm{M}$ deoxynucleotides, $10 \mathrm{U}$ RNasin (Promega) and $100 \mathrm{U}$ Superscript II (Gibco$\mathrm{BRL}$ ). This mixture was incubated for $75 \mathrm{~min}$ at $42^{\circ} \mathrm{C}$ and for $5 \mathrm{~min}$ at $75^{\circ} \mathrm{C}$. The gene expression levels of $B M P-2, A L P, O C$ and GAPDH were detected using the following primers: forward primer 5'-GCCAGCCGAGCCAACAC-3' and reverse primer 5'-AAATTAAAGAATCTCCGGGTTGT-3' for human BMP2; forward primer 5'-GAGCAGGAACAGAAGTTTGC-3' and reverse primer 5'-GTTGCAGGGTCTGGAGAGTA-3' for mouse ALP [34]; forward primer 5'-AGCTCAACCCCAATTGTGAC-3' and reverse primer 5'AGCTGTGCCGTCCATACTTT-3' for mouse OC [34]; and forward primer 5'-AACTCCCATTCCTCCACCTT3' and reverse primer 5'-GAGGGCCTCTCTCTTG CTCT-3' for mouse GAPDH [34]. Each primer (12.5 $\mathrm{pM}$ ) was added to a solution containing $12.5 \mu \mathrm{l}$ of iQ SYBR green supermix (Bio-Rad Laboratories) along with $0.5 \mu \mathrm{l}$ of template sample (final volume, $25 \mu \mathrm{l}$ ). The Mini Opticon real-time PCR system (Bio-Rad Laboratories Inc.) was used. The gene expression levels were expressed either as the delta cycle time $(\Delta C(t))$ or the delta-delta cycle time $(\Delta-\Delta \mathrm{C}(\mathrm{t}))$, and values normalized to GAPDH expression were compared with the gene expression in HAP-CP.

\section{BMP-2 and OC protein concentrations and ALP activity}

The cell-culture medium was used to measure the concentration of BMP-2 protein using the human/mouse/ rat BMP-2 Quantikine ELISA kit (R\&D Technologies Inc. RI, USA). Cells cultured on the substrate were lysed by freezing and thawing for three cycles in $200 \mu \mathrm{l}$ of PBS including 1\% TritonX-100. Then, the cell lysis solution was centrifuged at $12,000 \mathrm{~g}$ for $2 \mathrm{~min}$ at $4^{\circ} \mathrm{C}$. The supernatant was used to measure ALP activity using a LabAssay ALP activity kit (Wako Pure Chemical Industries, Ltd., Japan). Protein was quantified in the cell lysis supernatants using a micro-BCA protein assay kit (Thermo Fisher Scientific Inc., MA, USA). The concentration of $\mathrm{OC}$ protein in the culture medium was measured using a rat osteocalcin enzyme immunometric assay kit (Biomedical Technologies Inc., USA). The tissues inside the bone defect were homogenized in $400 \mu \mathrm{l}$ of PBS including 1\% Triton X-100, and then, the cell lysate solutions were centrifuged. The supernatant was used to measure the concentration of BMP-2 protein using a human/mouse/rat BMP-2 Quantikine ELISA kit (R\&D Technologies Inc.). Protein was quantified in the supernatant using a micro-BCA protein assay kit (Thermo Fisher Scientific Inc.). 


\section{Statistical analysis}

The experimental results are expressed as the mean \pm the standard deviation. All data were analyzed using Student's t-test, and probability values less than 0.05 were considered to be statistically significant.

\section{Results}

\section{Surface evaluation}

SEM and UV-vis results revealed that composite layers containing apatite had formed on EVOH and HAP treated in $\mathrm{CP}$ solution supplemented with plasmid and/or FB. A plasmid/FB/apatite composite layer formed in CP solution supplemented with $40 \mu \mathrm{g} / \mathrm{mL}$ plasmid and 10 $\mu \mathrm{g} / \mathrm{mL} \mathrm{FB}$, a plasmid/apatite composite layer formed in $\mathrm{CP}$ solution with $40 \mu \mathrm{g} / \mathrm{mL}$ plasmid, an $\mathrm{FB} /$ apatite composite layer formed in CP solution with $10 \mu \mathrm{g} / \mathrm{mL} \mathrm{FB}$, and an apatite layer formed in $\mathrm{CP}$ solution alone. As shown in the SEM images of EVOH in Figure 1, uniform layers were observed on the surfaces of all the samples. High magnification images (lower micrographs) show that all the layers had microflake-like architecture (Figure 2). The calcium dose, phosphate dose, plasmid content, and FB dose on the sample's surface were measured (Table 1).

\section{In-vitro evaluation of gene expression}

MC3T3-E1 and C3H10T1/2 cells were cultured on EVOH-DNA and EVOH-DNA-FB with pGL3 control DNA for 3 days, at which time luciferase assays were performed. In both the MC3T3-E1 and C3H10T1/2 cells, the relative luciferase units (RLUs) were a few times higher after growth on EVOH-DNA-FB than on EVOH-DNA (Figure 3). Next, the pGL3 control was switched to pCI-BMP, and the cells were cultured on each substrate for 3 days or 7 days. After 3 days, BMP-2 expression was a few fold higher in both cell lines after growth on EVOH-BMP-FB compared with EVOH-BMP (Figure 4A, B). After 7 days, numerous MC3T3-E1 cells had detached from both EVOH-BMP-FB and EVOH$\mathrm{BMP}$ due to cell confluence, and BMP-2 expression could not be evaluated (Figure 4A). Some C3H10T1/2 cells had detached and $B M P-2$ expression remained at the same level as that of the 3-day samples (Figure 4B). BMP-2 concentrations were measured in the 3 day-culture medium from both EVOH-BMP and EVOH-BMPFB. The BMP-2 concentration increased to over $600 \mathrm{pg} /$ $\mathrm{mL}$ in the $\mathrm{C} 3 \mathrm{H} 10 \mathrm{~T} 1 / 2$ cell-cultured medium (Figure $4 C)$. These findings suggested that the presence of $F B$ enhanced gene transfer in both the EVOH-BMP-FB and EVOH-DNA-FB substrates, and gene expression maybe sustained for one week.

\section{In-vitro bone development}

Bone induction in the MC3T3-E1 cells cultured on each substrate was evaluated by measuring ALP activity and OC protein levels. The MC3T3-E1 cells were cultured for 9 and 27 days and each assay was performed. In the cells grown on EVOH-BMP-FB, ALP activity increased with culturing time and was significantly higher than that in cells grown on EVOH-BMP at Day 27 (Figure $5 \mathrm{~A})$. OC levels were significantly higher when the cells were grown on EVOH-BMP-FB than on EVOH-BMP (Figure 5B). These findings indicate that BMP-2 expressed by gene transfer from EVOH-BMP or EVOHBMP-FB maintains its biological activity and induces bone development in MC3T3-E1 cells.

\section{In-vivo gene transfer}

Bone defect rat models treated with HAP-CP, HAPBMP, or HAP-BMP-FB were sacrificed 2 weeks after the procedure ( $n=3$ for each group). The tissues in the bone deficit were taken, $B M P-2$ gene expression was evaluated with real-time PCR using primers specific to human BMP-2 and BMP-2 concentrations in the tissues were assessed using the human/mouse/rat BMP-2 Quantikine ELISA kit (R\&D Technologies Inc.). BMP-2
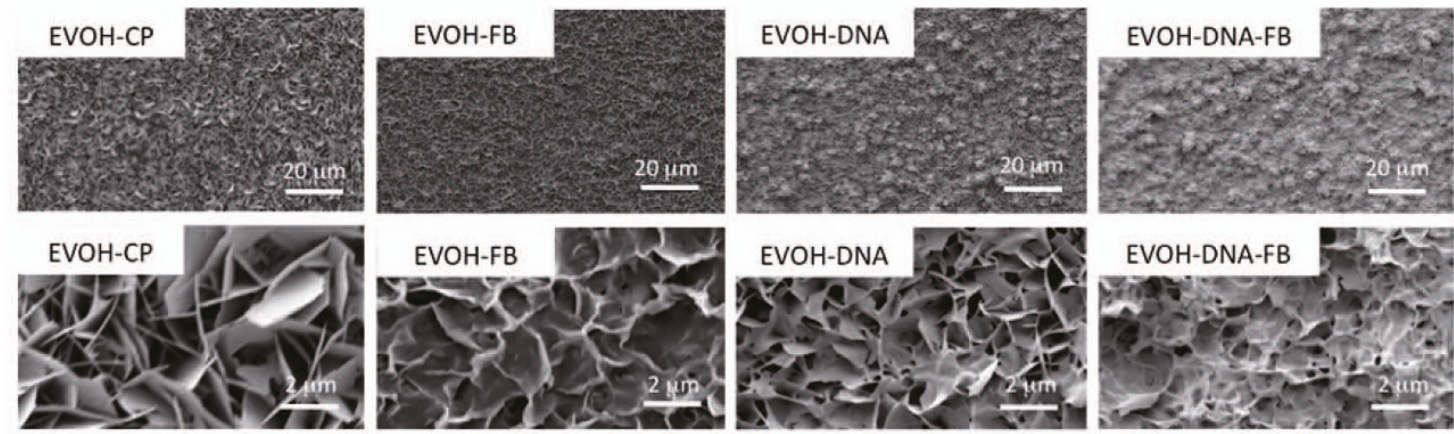

Figure 2 SEM photos of the EVOH-CP, EVOH-FB, EVOH-DNA and EVOH-DNA-FB substrates. Uniform layers were observed on the surfaces of all the samples. High magnification images (the lower micrographs) show that all these layers have a microflake-like architecture. 
Table 1 The immobilized doze of calcium, phosphate, DNA and FB

\begin{tabular}{lcccc}
\hline & $\begin{array}{c}\mathrm{Ca} \\
\left(\boldsymbol{\mu} \mathbf{g} / \mathbf{c m}^{2}\right)\end{array}$ & $\begin{array}{c}\mathbf{P} \\
\left(\boldsymbol{\mu g} / \mathbf{c m}^{2}\right)\end{array}$ & $\begin{array}{c}\text { DNA } \\
\left(\boldsymbol{\mu g} / \mathbf{c m}^{2}\right)\end{array}$ & $\begin{array}{c}\text { Fibronectin } \\
\left(\boldsymbol{\mu g} / \mathbf{c m}^{2}\right)\end{array}$ \\
\hline EVOH-CP & $119.7 \pm 4.385$ & $69.28 \pm 2.501$ & - & - \\
\hline EVOH-FB & $112.9 \pm 8.051$ & $57.57 \pm 3.265$ & - & $12.30 \pm 0.295$ \\
\hline EVOH-DNA & $86.57 \pm 6.841$ & $45.03 \pm 1.399$ & $12.22 \pm 0.287$ & - \\
\hline EVOH-DNA-FB & $108.2 \pm 3.021$ & $57.64 \pm 3.370$ & $14.00 \pm 0.579$ & $17.84 \pm 1.332$ \\
\hline & $\begin{array}{c}\mathrm{Ca} \\
\left(\mu \mathrm{g} / \mathrm{cm}^{2}\right)\end{array}$ & $\begin{array}{c}\mathrm{P} \\
\left(\mu \mathrm{g} / \mathrm{cm}^{2}\right)\end{array}$ & $\begin{array}{c}\mathrm{Fibronectin} \\
\left(\mu \mathrm{g} / \mathrm{cm}^{2}\right)\end{array}$ \\
\hline HAP-CP & $156.4 \pm 8.187$ & $67.99 \pm 4.043$ & - & - \\
\hline HAP-BMP & $205.9 \pm 11.87$ & $68.21 \pm 7.473$ & $16.04 \pm 0.905$ & - \\
\hline HAP-BMP-FB & $158.6 \pm 13.63$ & $42.09 \pm 2.820$ & $18.62 \pm 2.701$ & $19.60 \pm 1.327$ \\
\hline
\end{tabular}

gene expression was higher in the tissues treated with HAP-BMP-FB than in those treated with HAP-BMP or HAP-CP (Figure 6A). The BMP-2 concentration was approximately $108 \mathrm{pg} / \mathrm{mg}$ in HAP-BMP-FB, which was higher than that in HAP-BMP or HAP-CP (Figure 6B). These results suggest that the in-vivo gene transfer ability of HAP-BMP-FB is higher than that of HAP-BMP.

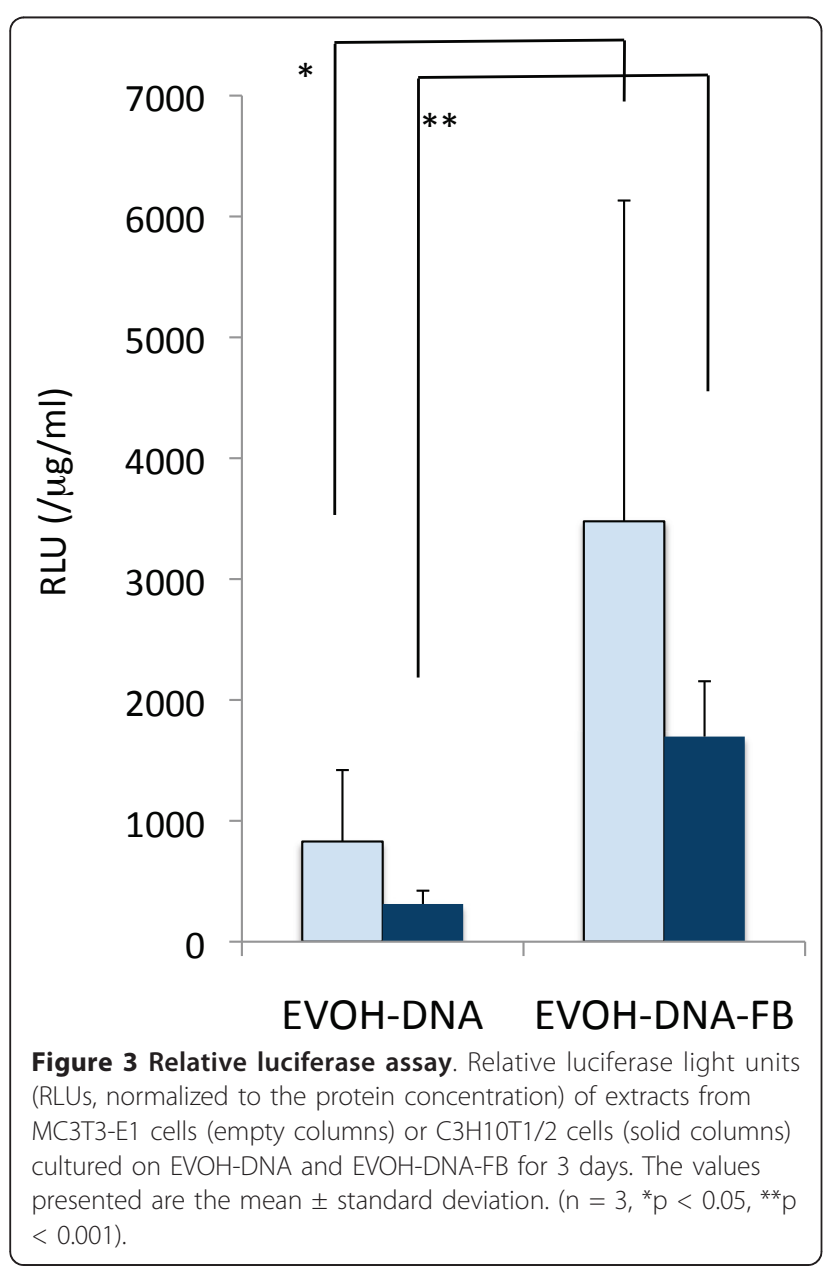

\section{In-vivo bone development}

The rat models with a bone deficit treated with HAPCP, HAP-BMP, or HAP-BMP-FB were sacrificed 8 weeks after the procedure ( $n=5$ for each group). Bone formation was quantified by measuring the length of new bone extension into the inside of the bone defect and the thickness of the edges of the bone defect [23]. Small pieces of tissues in the bone defect were taken, and the expression levels of the $A L P$ and $O C$ genes were evaluated. Figure 7A shows histological sections of bone formation at the edge of the cranium in the bone defect. In the HAP-BMP-FB group, bone formation was enhanced significantly more than in the HAP-BMP and HAP-CP groups (Figure 7B). The expression levels of the $A L P$ and $O C$ genes increased more in the HAPBMP-FB group than in the HAP-BMP or HAP-CP groups (Figure $7 \mathrm{C}$ ). These findings suggest that HAPBMP-FB enhances bone formation more than HAPBMP or HAP-CP.

\section{Discussion}

Non-viral gene transfer systems are easier to use and safer than viral gene transfer systems, but it is difficult to obtain a high gene transfer ratio $[35,36]$. Low gene transfer ratios have limited the application of non-viral gene transfer systems. Cytokines require an effective concentration to exert their biological effects, and cytokine production is a component of certain gene therapies. Therefore, we have been trying to improve the gene transfer ratio of our non-viral gene transfer systems [18-20]. Some non-viral gene transfer systems exhibit a degree of cytotoxicity because certain of their components (such as phospholipids) are administered in-vivo in high amounts. The cytotoxicity of the components of non-viral gene transfer systems must be taken into account. The elements used in our gene transfer system are DNA, calcium phosphate, and adhesion protein, which are thought safe. In this study, we evaluated whether our system provides gene transfer ratios high 

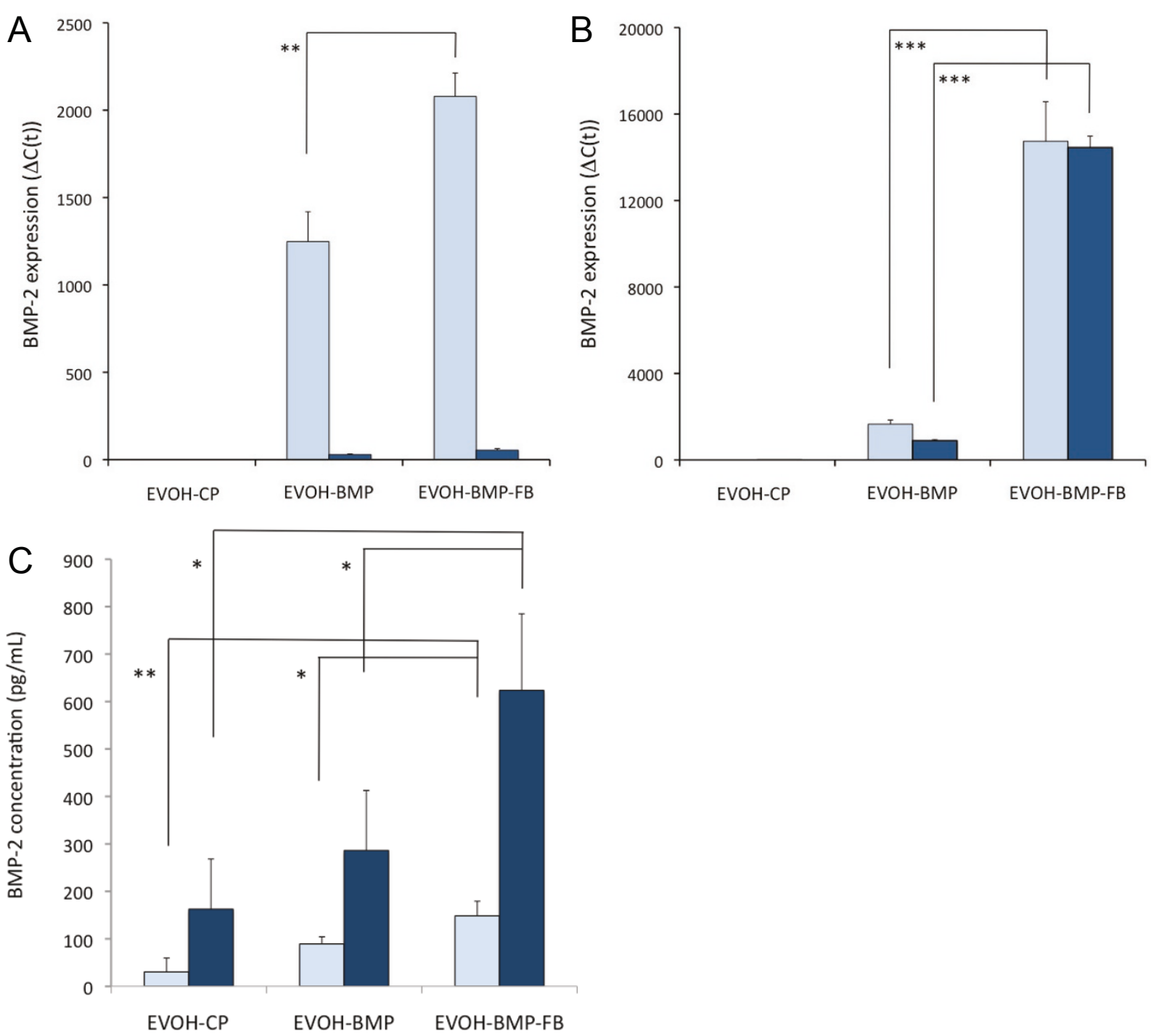

Figure 4 BMP-2 gene expression levels and BMP-2 protein concentrations in in-vitro experiments. BMP2 gene expression levels in extracts from MC3T3-E1 cells (A) or C3H10T1/2 cells (B) cultured on EVOH-CP, EVOH-BMP, or EVOH-BMP-FB for 3 or 7 days. The empty columns indicate a 3-day culture and the solid columns a 7-day culture. (C) BMP-2 concentrations in the medium from cells cultured on EVOH-CP, EVOH-BMP or EVOH-BMP-FB for 7 days. The empty columns indicate the MC3T3-E1 cells and the solid columns the C3H10T1/2 cells. The values presented are the mean \pm standard deviation. $\left(n=3,{ }^{*} p<0.05,{ }^{* *} p<0.01,{ }^{* * *} p<0.001\right)$.

enough to have biological effects and thus to have potential for in-vivo applications.

Nie et al. reported a BMP-2 gene therapy system that uses DNA/chitosan nanoparticles [37]. In this study, the successful case in which bone formation was enhanced showed serum BMP-2 levels of approximately $3.5 \mathrm{ng} /$ $\mathrm{mL}$ instead of approximately $1 \mathrm{ng} / \mathrm{mL}$ in the control case. The biologically effective concentration of BMP-2 protein was reported to be over $4.3 \mathrm{ng} / \mathrm{mL}$, and it can act in a dose-dependent manner [38]. Our gene transfer system achieved $108 \mathrm{pg} / \mathrm{mg}$ of BMP-2 protein in tissue, a level roughly twice that observed with HAP-CP. Even if successful, in non-viral gene therapy the therapeutic protein concentration might only increase to several times that of the control. Our BMP-2 gene-FB-apatite composite layer might stimulate osteoblasts in-vivo. Indeed, our experiments indicated that HAP-BMP-FB enhanced bone formation in. In some studies using slow-releasing BMP-2 protein systems, micrograms of proteins were immobilized in a slow-releasing material, which might be too much considering its biologically effective concentration $[39,40]$. Indeed, ectopic bone formation and bony overgrowths were induced in one such clinical trial, which might have been due to the overdose. Our system induces BMP-2 protein at low concentrations and thus might not have the toxicity and 

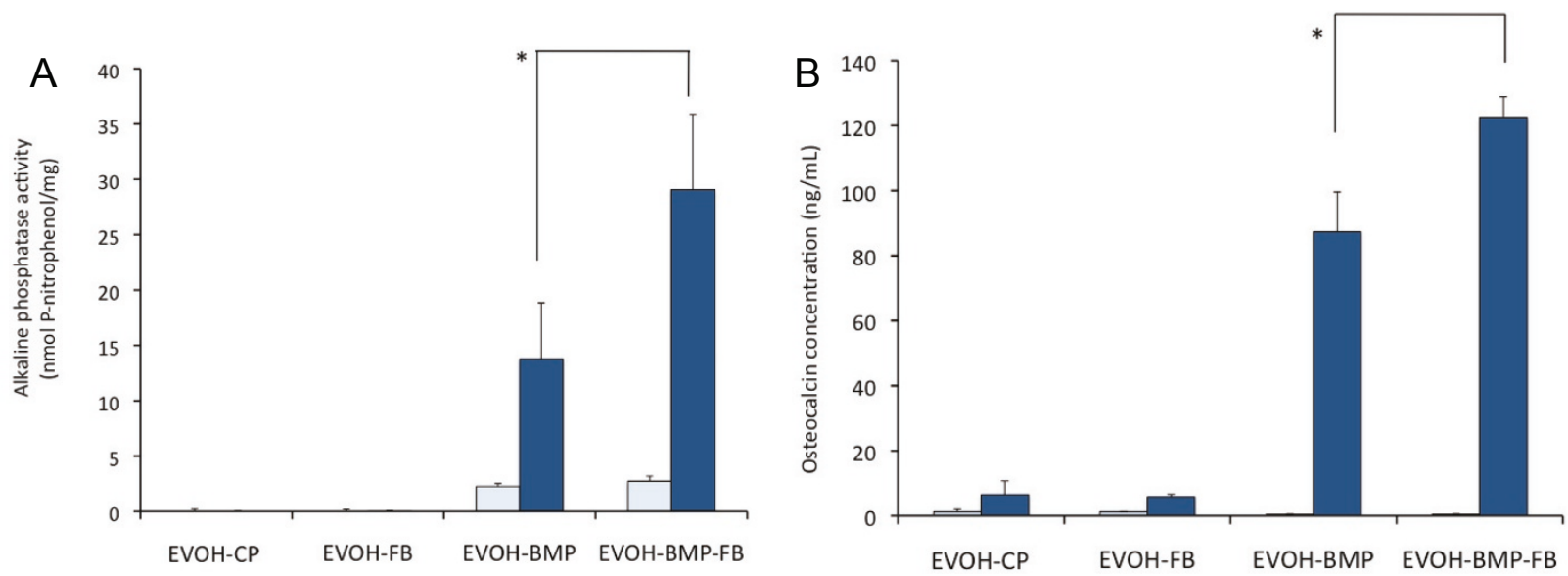

Figure 5 Development of MC3T3-E1 cells in in-vitro experiments. A; Alkaline phosphatase activity of cells cultured on $E V O H-C P, E V O H-F B$, EVOH-BMP or EVOH-BMP-FB for 9 or 27 days. B; Osteocalcin concentration of cells cultured on EVOH-CP, EVOH-FB, EVOH-BMP or EVOH-BMP-FB for 9 or 27 days. The empty columns indicate a 9-day culture and the solid columns a 27-day culture. The values presented are the mean \pm standard deviation. $\left(n=3,{ }^{*} p<0.01\right)$.

resulting side effects. Systems with high antigenicity, such as adenovirus vector systems, can induce inflammation, which influences tissue regeneration. We thought that the low toxicity of the applied system was an important factor for tissue engineering. Our gene transfer system consists of phosphate, calcium, plasmid DNA and FB, which all have low toxicity. Histological examination revealed no inflammation and no necrosis, indicating that our gene transfer system has good tissue compatibility. Thus, this system has promise for in-vivo applications and merits further evaluation.

We have researched the incorporation of functional molecules (such as genes and proteins) into apatite composite layers and the addition of such molecules to
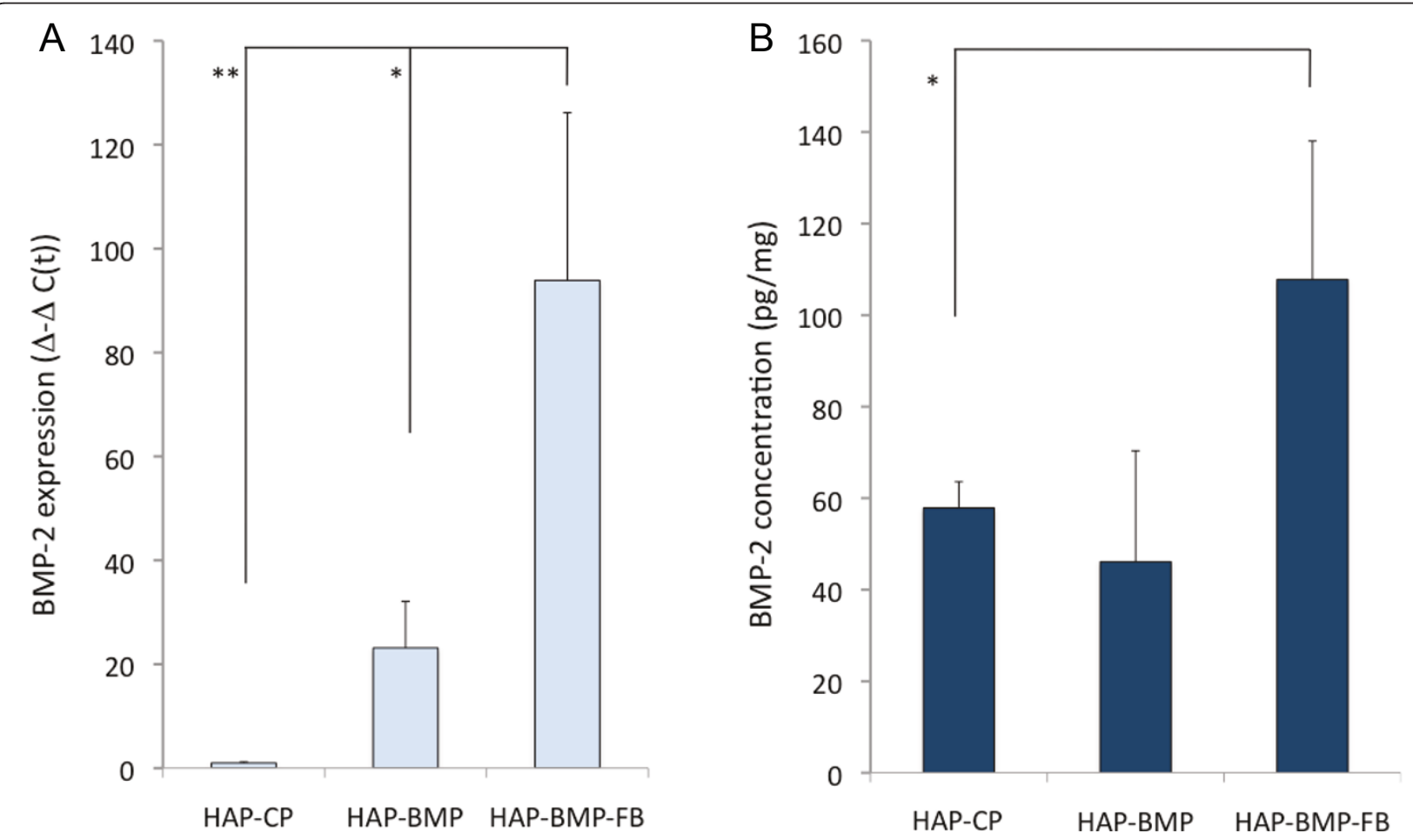

Figure 6 BMP-2 gene expression and BMP-2 protein concentrations in animal experiments. $B M P-2$ gene expression (A) and $B M P-2$ protein concentrations (B) were evaluated in bone defect tissue treated with HAP-CP, HAP-BMP or HAP-BMP-FB two weeks after the procedure. The values presented are the mean \pm standard deviation $\left(n=3,{ }^{*} p<0.05,{ }^{* *} p<0.01\right)$. 
A
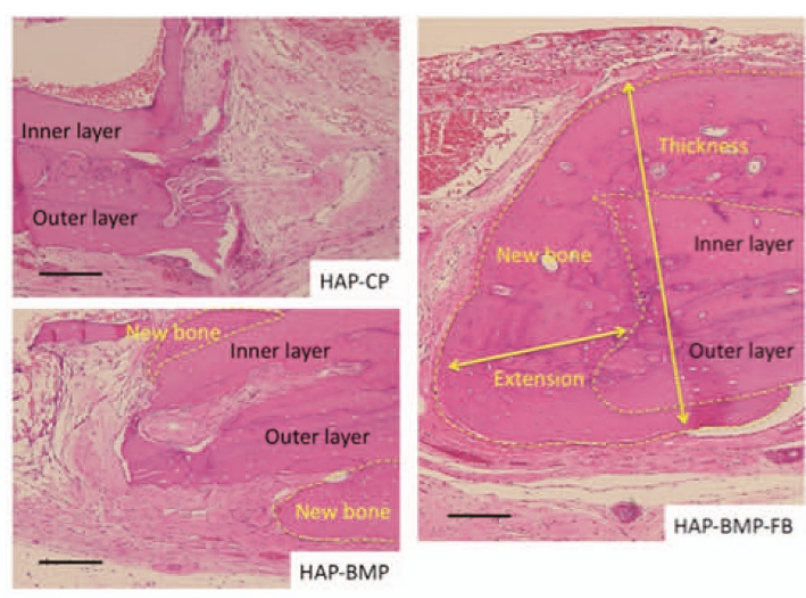

\section{B}

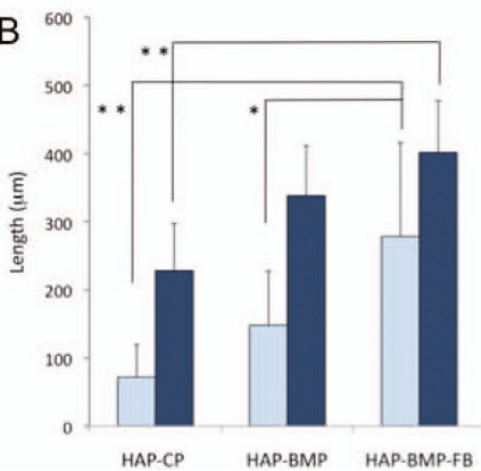

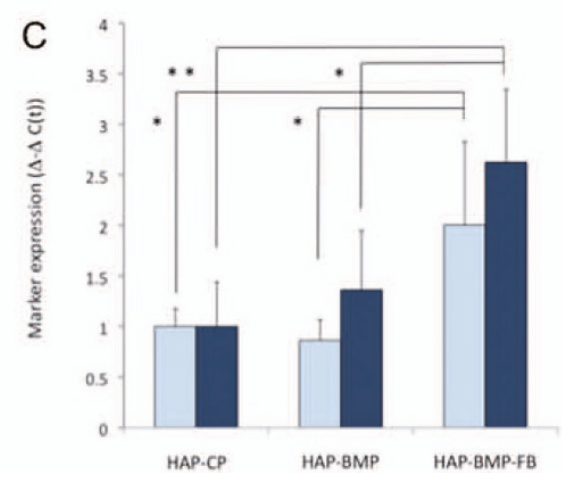

Figure 7 Evaluation of the animal experiments. A; Histological sections of the bone defects were stained with hematoxylin and eosin after demineralization. The bone defects were treated with HAP-CP, HAP-BMP or HAP-BMP-FB 8 weeks ago. The yellow dotted lines show the area of bone formation (indicated by new bone). Bone formation was observed between the cranium and the dural membrane, resulting in increased cranial thickness. Bone formation was also observed in the bone defect space as the extension of new bone. Bars indicate $100 \mu \mathrm{m}$. B; Bone formation was quantified in each group. The extension of new bone into the space left by the bone defect (open columns). The increased thickness of the cranium due to the bone formation (solid columns). The values presented are the mean \pm standard deviation. ( $n=5$, * $p<0.05$, $\left.{ }^{* *} p<0.01\right) C ; A L P$ and $O C$ gene expression in the bone defect tissue 8 weeks after the procedure. Open columns indicate ALP gene expression and solid columns indicate $O C$ expression. The values presented are the mean \pm standard deviation $\left(n=5,{ }^{*} p<0.05,{ }^{* *} p<0.01\right)$.

the surface of substrates coated with an apatite layer. The ability of incorporated FB to affect gene transfer efficiency is described in our previous report [18-20]. Briefly, cell adhesion molecules (such as FB or laminin) incorporated into a gene-apatite composite layer enhance cell adhesion and cell spreading on the surface of the layer, thereby enlarging the contact area between the cell and the layer. Because of the tight binding between the cell adhesion molecule ligands and the receptors on the cell surface, a stagnant microenvironment is produced at the enlarged contact area between the cell and the layer. The resulting microenvironment is gradually enriched with DNA molecules that are released from the layer. As a result, highly efficient gene transfer is accomplished at the cell adhesion moleculegene apatite composite layer. In this study, HAP-BMPFB tightly bound to cells, perhaps mostly fibroblasts, in the surrounding tissues and transferred the BMP-2 gene. $B M P$-2 gene expression was detected for one week in in-vitro experiments and for 2 weeks in in-vivo experiments, which might indicate that our gene transfer system slowly releases the DNA. However, our other reports have shown that the expression of transferred genes peaks from 3 days to 7 days in in-vitro experiments [18-20]. It was unclear when the gene expression peaked in the in-vivo experiments. As bone formation was observed in the in-vivo experiments despite only a two-fold increase in BMP-2 levels in the HAP-BMP-FB group over the HAP-BMP or HAP-CP group, the peak BMP-2 concentration might occur at an early stage and its value might be higher. Additional pharmaco-dynamic evaluations should be performed in the future. Considering that cytokines would have to be administered for an extended period to develop tissue progenitor cells, a slow releasing gene would be convenient in tissue engineering. Induced paracrine secretion of BMP-2 protein in the bone defect could stimulate the surrounding osteoblasts. Our treatment system would be useful in 
bone engineering. However, longer-term experiments using animals should be planned to further evaluate the speed and quality of bone formation, because twentyfour weeks might be necessary for cranial defects to completely heal in this rat model [41].

We hope that the apatite composite layer including plasmid and FB might be applied for cranioplasty. In the future, the use of our treatment system in biomaterials could facilitate bone fusion at early stages after cervical operations.

\section{Conclusion}

The $B M P$-2 gene-FB-apatite composite layer was able to enhance bone formation and may be useful for bone engineering. Our gene transfer system might be a useful tool for tissue engineering applications, because it has the potential to control cell differentiation and is both safe and highly efficient.

\section{Acknowledgements}

This work was supported by a Grant-in-Aid for Scientific Research (JSPS postdoctoral fellowship) (19-07607) from the Japan Society for the Promotion of Science, and a Grant-in-Aid for young scientists (B) (22700499) from the Ministry of Education, Culture, Sport, Science and Technology of Japan.

\section{Author details}

${ }^{1}$ Nanosystem Research Institute (NRI), National Institute of Advanced Industrial Science and Technology (AIST), Higashi 1-1-1, Tsukuba, Ibaraki 3058565, Japan. ${ }^{2}$ Department of Neurosurgery, Graduate School of Comprehensive Human Science, University of Tsukuba, Tennoudai 1-1-1, Tsukuba, Ibaraki 305-8575, Japan. ${ }^{3}$ Institute of Human Science and Biomedical Engineering, National Institute of Advanced Industrial Science and Technology (AIST), Higashi 1-1-1, Tsukuba, Ibaraki 305-8565, Japan. ${ }^{4}$ Technical Institute of Physics and Chemistry, Chinese Academy of Sciences, Beijing 100190, China.

\section{Authors' contributions}

WZ, HT and AM conceived of the study, participated in its design and coordination, and helped to draft the manuscript. $A O$ and $Y Y$ studied the gene-fibronectin-apatite composite layer. YS and Al prepared the hydroxyapatite buttons that were used in the animal experiments. All authors read and approved the final manuscript.

\section{Competing interests}

The authors declare that they have no competing interests.

Received: 29 April 2011 Accepted: 23 August 2011

Published: 23 August 2011

\section{References}

1. Riew KD, Wright NM, Cheng S, Avioli LV, Lou J: Induction of bone formation using a recombinant adenoviral vector carrying the human BMP-2 gene in a rabbit spinal fusion model. Calcif Tissue Int 1998, 63:357-360.

2. Alden TD, Beres EJ, Laurent JS, Engh JA, Das S, London SD, Jane JA Jr, Hudson SB, Helm GA: The use of bone morphogenetic protein gene therapy in craniofacial bone repair. J Craniofac Surg 2000, 11:24-30.

3. Baltzer AW, Lattermann C, Whalen JD, Wooley P, Weiss K, Grimm M, Ghivizzani SC, Robbins PD, Evans CH: Genetic enhancement of fracture repair: healing of an experimental segmental defect by adenoviral transfer of the BMP-2 gene. Gene Ther 2000, 7:734-739.

4. Lieberman JR, Daluiski A, Stevenson S, Wu L, McAllister P, Lee YP, Kabo JM, Finerman GA, Berk AJ, Witte ON: The effect of regional gene therapy with bone morphogenetic protein-2-producing bone-marrow cells on the repair of segmental femoral defects in rats. J Bone Jt Surg Am 1999, 81:905-917.

5. Engstrand T, Daluiski A, Bahamonde ME, Melhus H, Lyons KM: Transient production of bone morphogenetic protein 2 by allogeneic transplanted transduced cells induces bone formation. Hum Gene Ther 2000, 11:205-211.

6. Olmsted EA, Blum JS, Rill D, Yotnda P, Gugala Z, Lindsey RW, Davis AR: Adenovirus-mediated BMP2 expression in human bone marrow stromal cells. J Cell Biochem 2001, 82:11-21.

7. Gelse K, von der MK, Aigner T, Park J, Schneider H: Articular cartilage repair by gene therapy using growth factor-producing mesenchymal cells. Arthritis Rheum 2003, 48:430-441.

8. Park J, Ries J, Gelse K, Kloss F, von der Mark K, Wiltfang J, Neukam FW Schneider $\mathrm{H}$ : Bone regeneration in critical size defects by cell-mediated BMP-2 gene transfer: a comparison of adenoviral vectors and liposomes. Gene Ther 2003, 10:1089-1098.

9. Park J, Gelse K, Frank S, von der MK, Aigner T, Schneider H: Transgeneactivated mesenchymal cells for articular cartilage repair: a comparison of primary bone marrow-, perichondrium/periosteumand fat-derived cells. J Gene Med 2006, 8:112-125.

10. Wang EA, Rosen V, D'Alessandro JS, Bauduy M, Cordes P, Harada T, Israel DI, Hewick RM, Kerns KM, LaPan P, et al: Recombinant human bone morphogenetic protein induces bone formation. Proc Natl Acad Sci USA 1990, 87:2220-2224

11. Sellers RS, Zhang R, Glasson SS, Kim HD, Peluson D, D'Augusta DA, Beckwith K, Morris EA: Repair of articular cartilage defects one year after treatment with recombinant human bone morphogenetic protein-2 (rhBMP-2). J Bone Jt Surg Am 2000, 82:151-160.

12. Graham FL, van der Eb AJ: A new technique for the assay of infectivity of human adenovirus 5 DNA. Virology 1973, 52:456-467.

13. Batard $\mathrm{P}$, Jordan M, Wurm F: Transfer of high copy number plasmid into mammalian cells by calcium phosphate transfection. Gene 2001, 270:61-68.

14. Roy I, Mitra S, Maitra A, Mozumdar S: Calcium phosphate nanoparticles as novel non-viral vectors for targeted gene delivery. Int J Pharm 2003, 250:25-33.

15. Jarcho M, Kay JF, Drobeck HP, Dremus RH: Tissue cellular and subcellular events at bone-ceramic hydroxyapatite interface. J Bioeng 1976, 1:79-92.

16. Aoki H: Science and Medical Applications of Hydroxyapatite Takayama Press System Center Co. Inc.; Tokyo; 1991.

17. Shen H, Tan J, Saltzman WM: Surface-mediated gene transfer from nanocomposites of controlled texture. Nature Mater 2004, 3:569-574

18. Oyane A, Tsurushima $H$, Ito A: Novel gene-transferring scaffolds having a cell adhesion molecule-DNA-apatite nanocomposite surface. Gene Ther 2007, 14:1750-1753.

19. Oyane A, Murayama M, Yamazaki A, Sogo Y, Ito A, Tsurushima H: Fibronectin-DNA-apatite composite layer for highly efficient and areaspecific gene tranfer. J Biomed Mater Res A 2010, 92:1038-1047.

20. Oyane A, Tsurushima $H$, Ito A: Highly efficient gene transfer system using a lamini-DNA-apatite composite layer. J Gene Med 2010, 12:194-206.

21. Pompili A, Caroli F, Carpanese L, Caterino M, Raus L, Sestili G, Occhiointi E: Cranioplasty performed with a new osteoconductive, osteoinducing hydroxyapatitederived material. J Neurosurg 1998, 89:236-242.

22. Sanan A, Haines SJ: Repairing holes in the head: a history of cranioplasty. J Neurosurg 1997, 40:588-603.

23. Tsurushima H, Marushima A, Suzuki K, Oyane A, Sogo Y, Nakamura K, Matsumura A: Enhanced bone formation using hydroxyapatite ceramic coated with fibroblast growth factor-2. Acta Biomater 2010, 6:2751-2759

24. Oyane A, Tsurushima H, Ito A: Simple surface modification process to produce a transparent apatite-polystyrene composite for in situ observation of cell behavior. Chem Lett 2006, 35:1300-1301.

25. Oyane A, Uchida M, Choong C, Triffitt J, Jones J, Ito A: Simple surface modification of poly( $\varepsilon$-caprolactone) for apatite deposition from simulated body fluid. Biomaterials 2005, 26:2407-2413.

26. Oyane A, Uchida M, Yokoyama Y, Choong C, Triffitt J, Ito A: Simple surface modification of poly( $\varepsilon$-caprolactone) to induce its apatite-forming ability. J Biomed Mater Res A 2005, 75:138-145.

27. Taguchi T, Kishida A, Akashi M: Hydroxyapatite formation on/in hydrogels using a novel alternate soaking process. Chem Lett 1998, 27:711-712 
28. Oyane A, Uchida M, Ishihara Y, Ito A: Ultra-structural study of the lamininapatite composite layer formed on ethylene-vinyl alcohol copolymer by a biomimetic process. Key Eng Mater 2005, 284-6:227-230.

29. Oyane A, Uchida M, Ito A: Laminin-apatite composite coating to enhance cell adhesion to ethylene-vinyl alcohol copolymer. J Biomed Mater Res A 2005, 72:168-174.

30. Oyane A, Uchida M, Onuma K, Ito A: Spontaneous growth of a lamininapatite nano-composite in a metastable calcium phosphate solution. Biomaterials 2006, 27:167-175.

31. Uchida M, Oyane A, Kim HM, Kokubo T, Ito A: Biomimetic coating of laminin-apatite composite on titanium metal with excellent cell adhesive property. Adv Mater 2004, 16:1071-1074.

32. Cuevas P, de Paz V, Cuevas B, Marin-Martinez J, Picon-Mokina M, FernándezPereira A, Giménez-Gallego G: Osteopromotion for cranioplasty: an experimental study in rats using acidic fibroblast growth factor. Surg Neurol 1997, 47:242-246.

33. Petrie Aronin CE, Sadik KW, Lay AL, Rion DB, Tholpady SS, Ogle RC, Botchwey EA: Comparative effects of scaffold pore size, pore volume, and total void on cranial bone healing patterns using microspherebased scaffolds. J Biomed Mater Res A 2009, 89:632-641.

34. Ranieri AD, Virdi AS, Kuroda S, Shott S, Dai Y, Sumner DR: Local application of rhTGF-b2 modulates dynamic gene expression in a rat implant model. Bone 2005, 36:931-940.

35. Verma IM, Somia N: Gene therapy-promises, problems and prospects. Nature 1997, 389:239-242.

36. Gao X, Huang L: Cationic liposome-mediated gene transfer. Gene Ther $1995,2: 710-722$

37. Nie H, Ho ML, Wang CK, Wang CH, Fu YC: BMP-2 plasmid loaded PLGA/ Hap composite scaffolds for treatment of bone defects in nude mice. Biomaterials 2009, 30:892-901.

38. Chaudhari A, Ron E, Rethman MP: Recombinant human bone morphogenetic protein-2 stimulates differentiation in primary cultures of fetal rat calvarial osteoblasts. Mol Cell Biochem 1997, 167:31-39.

39. Benglis $D$, Wang MY, Levi AD: A comprehensive review of the safety profile of bone morphogenetic protein in spine surgery. Neurosurgery 2008, 62:ONS423-ONS431.

40. Fahim DK, Whitehead WE, Curry DJ, Dauser RC, Luerssen TG, Jea A: Routine use of recombinant human bone morphogenetic protein-2 in posterior fusions of the pediatric spine: Safety profile and efficacy in the early postoperative period. Neurosurgery 2010, 67:1195-1204.

41. Silva RV, Camilli JA, Bertran CA, Moreira NH: The use of hydroxyapatite and autogenous cancellous bone grafts to repair bone defects in rats. Int $J$ Oral Maxillofac Surg 2005, 34:178-184.

doi:10.1186/1423-0127-18-62

Cite this article as: Zhang et al:: BMP-2 gene-fibronectin-apatite

composite layer enhances bone formation. Journal of Biomedical Science 2011 18:62

\section{Submit your next manuscript to BioMed Central and take full advantage of:}

- Convenient online submission

- Thorough peer review

- No space constraints or color figure charges

- Immediate publication on acceptance

- Inclusion in PubMed, CAS, Scopus and Google Scholar

- Research which is freely available for redistribution 